\title{
Interactions between HIV infection and chronic obstructive pulmonary disease: Clinical and epidemiological aspects
}

\author{
Christine Raynaud $^{1 *+}$, Nicolas Roche ${ }^{2 \dagger}$ and Christos Chouaid ${ }^{3+}$
}

\begin{abstract}
Introduction: An association between HIV infection and chronic obstructive pulmonary disease (COPD) has been observed in several studies.

Objective and methods: we conducted a review of the literature linking HIV infection to COPD, focusing on clinical and epidemiological data published before and during widespread highly active antiretroviral therapy (HAART).

Results: Interactions between HIV infection and COPD appear to be influenced by multiple factors. In particular, the bronchopulmonary tract can be damaged by HIV infection, the immunodeficiency it induces, and the resulting increase in the risk of pulmonary infections. In addition, the prevalence of smoking and intravenous drug use is higher in HIV-infected populations, also increasing the risk of COPD. Before the advent of HAART, respiratory tract infections probably played a major role. Since the late 1990s and the widespread use of HAART, the frequency of opportunistic infections has fallen but new complications have emerged as life expectancy has increased.
\end{abstract}

Conclusion: given the high prevalence of smoking among HIV-infected patients, COPD may contribute significantly to morbidity and mortality in this setting.

\section{Introduction}

Chronic obstructive pulmonary disease (COPD) is defined by slowly progressive, incompletely reversible chronic airflow obstruction. Smoking is the main risk factor but the mechanisms linking smoking to COPD are not completely clear, although they are known to involve inflammation, oxidative stress, proteolytic injury and both innate and acquired immunity [1,2]. Active smoking and frequent exacerbations (often related to lower respiratory tract viral or bacterial colonization and infection) are associated with COPD progression, but other factors may be involved.

The possibility of an increased susceptibility of HIVinfected patients to COPD has been raised in recent years [3-5]. Both HIV infection per se and the resulting immune response have been implicated. Moreover,

\footnotetext{
* Correspondence: christine.raynaud@ch-argenteuil.fr

+ Contributed equally

'Service de pneumologie, Centre Hospitalier Victor Dupouy, 69 rue du L.C. Prud'hon, 95100 Argenteuil, France

Full list of author information is available at the end of the article
}

HIV-infected patients appear to be at a particular risk of developing COPD, owing to their high prevalence of smoking, recurrent pulmonary infections (including opportunistic infections), frequent drug use, and often precarious socio-economic status [5]. However, these features also represent confounding factors in analyses of the possible association between COPD and HIV infection [5].

The impact of highly active antiretroviral therapy (HAART) adds to the complexity of this issue. HAART consists of a combination of at least three antiretroviral drugs taken simultaneously and regularly in order to achieve a maximal reduction in viral load [6]. During the pre-HAART period, mortality among HIV-infected patients was mainly due to opportunistic infections. Since the end of the 1990s and widespread HAART use, life expectancy of HIV-infected subjects has increased and new complications have emerged $[7,8]$. The high prevalence of smoking in this now aging HIV-infected population means that COPD may be a significant source of morbidity and mortality $[4,9]$. 
The aim of this literature review is to examine interactions between HIV infection and COPD, focusing on clinical and epidemiological data published in the preHAART and HAART eras.

\section{COPD-HIV interaction in the pre-HAART period (Table 1)}

Several studies have examined the link between HIV infection and bronchial hyper-responsiveness, a possible early sign of airway damage. The prevalence of bronchial hyper-responsiveness is not significantly influenced by HIV infection [10-12]. In contrast, the prevalence of bronchial hyper-responsiveness seems to be higher among HIV-infected male smokers (enrolled between 1995 and 1996) than in their seronegative counterparts, suggesting that HIV-infected men may be more sensitive to the consequences of smoking [10].

Another study (conducted between 1993 and 1998) showed a higher frequency of chronic bronchitis (defined as near-daily expectoration for three months or more per year) in HIV-infected patients than in a control group (26.9\% versus $13.5 \%, \mathrm{p}<0.05)$, despite a similar proportion of current smokers (about 50\%) and a

Table 1 Main published studies on COPD-HIV interaction in the pre-HAART era

\begin{tabular}{|c|c|c|c|c|c|c|}
\hline $\begin{array}{l}\text { Year of } \\
\text { publication }\end{array}$ & $\begin{array}{c}\text { First } \\
\text { author } \\
\text { Reference }\end{array}$ & $\begin{array}{l}\text { Study } \\
\text { period }\end{array}$ & $\begin{array}{l}\text { Type of } \\
\text { study }\end{array}$ & Focus & $\begin{array}{c}\text { Number } \\
\text { of } \\
\text { patients }\end{array}$ & Main findings \\
\hline 1993 & $\begin{array}{c}\text { Moscato G } \\
{[12]}\end{array}$ & NR & $\begin{array}{l}\text { "One day" } \\
\text { Case-control }\end{array}$ & $\begin{array}{l}\text { Bronchial hyper- } \\
\text { responsiveness }\end{array}$ & $\begin{array}{c}25 \\
(25 \\
\text { controls })\end{array}$ & $\begin{array}{l}\text { Prevalence of bronchial hyper-responsiveness identical in the } \\
\text { two populations }\end{array}$ \\
\hline 1997 & $\begin{array}{l}\text { Wallace } \\
\text { JM [11] }\end{array}$ & $\begin{array}{c}1988- \\
1994\end{array}$ & $\begin{array}{c}\text { Cohort } \\
\text { Case-control }\end{array}$ & $\begin{array}{l}\text { Bronchial hyper- } \\
\text { responsiveness }\end{array}$ & $\begin{array}{c}62 \\
(62 \\
\text { controls })\end{array}$ & $\begin{array}{l}\text { Prevalence of bronchial hyper-responsiveness identical in the } \\
\text { two populations }\end{array}$ \\
\hline 2001 & $\begin{array}{l}\text { Poirier CD } \\
\quad[10]\end{array}$ & $\begin{array}{c}1995- \\
1996\end{array}$ & $\begin{array}{l}\text { prospective } \\
\text { Case-control }\end{array}$ & $\begin{array}{l}\text { Bronchial hyper- } \\
\text { responsiveness }\end{array}$ & $\begin{array}{c}248 \\
(236 \\
\text { controls })\end{array}$ & $\begin{array}{c}\text { Prevalence of bronchial hyper-responsiveness identical in the } \\
\text { two populations Among smokers, bronchial hyper- } \\
\text { responsiveness more frequent in HIV-infected men than in } \\
\text { controls }\end{array}$ \\
\hline 2003 & $\begin{array}{l}\text { Diaz PT } \\
\text { [13] }\end{array}$ & $\begin{array}{c}1993- \\
1998\end{array}$ & $\begin{array}{c}\text { Cohort } \\
\text { Case-control }\end{array}$ & Chronic bronchitis & $\begin{array}{c}327 \\
(52 \\
\text { controls })\end{array}$ & $\begin{array}{l}\text { Chronic bronchitis more frequent in HIV-infected patients than } \\
\text { in controls }(26.9 \% \text { versus } 13.5 \%, p<0.05)\end{array}$ \\
\hline 1998 & $\begin{array}{l}\text { Shaw RJ } \\
\text { [16] }\end{array}$ & NR & $\begin{array}{l}\text { Prospective? } \\
\text { descriptive }\end{array}$ & Airway obstruction & 34 & $\begin{array}{l}\text { Lung infections (PCP, bacterial pneumonia) associated with } \\
\text { lower FEV } 1 \text { and peak flow rates }\end{array}$ \\
\hline 1988 & $\begin{array}{l}\text { O'Donnell } \\
\text { CR [14] }\end{array}$ & $\begin{array}{c}1983- \\
1986\end{array}$ & Retrospective? & Airway obstruction & $\begin{array}{c}99 \\
(\text { AIDS) }\end{array}$ & Estimated prevalence of lower forced expiratory. flow rates: $33 \%$ \\
\hline 1999 & $\begin{array}{l}\text { Gelman M } \\
\quad[15]\end{array}$ & NR & $\begin{array}{l}\text { Prospective } \\
\text { Case-control }\end{array}$ & Air trapping/CT & $\begin{array}{c}48 \\
(11 \\
\text { controls) }\end{array}$ & Degree of air trapping correlated with duration of HIV infection \\
\hline 2000 & $\begin{array}{l}\text { Hnizdo E } \\
\quad[18]\end{array}$ & $\begin{array}{c}1995- \\
1996\end{array}$ & $\begin{array}{c}\text { Cohort } \\
\text { Case-control }\end{array}$ & $\begin{array}{l}\text { Impairment of lung } \\
\text { function and } \\
\text { tuberculosis }\end{array}$ & $\begin{array}{c}305 \\
(1038 \\
\text { controls })\end{array}$ & $\begin{array}{l}\text { Functional respiratory decline due to tuberculosis not } \\
\text { aggravated by HIV co infection }\end{array}$ \\
\hline 2000 & $\begin{array}{l}\text { Morris AM } \\
\quad[17]\end{array}$ & $\begin{array}{l}1988^{-} \\
1994\end{array}$ & $\begin{array}{c}\text { Cohort } \\
\text { descriptive }\end{array}$ & Airway obstruction & 141 & $\begin{array}{c}\text { Acceleration of decline in } \mathrm{FEV}_{1}, \mathrm{FVC} \text { and } \mathrm{FEV}_{1} / \mathrm{FVC} \text {, for several } \\
\text { months after acute episode }\end{array}$ \\
\hline 1989 & $\begin{array}{l}\text { Kuhlman } \\
\text { JE [21] }\end{array}$ & NR & $\begin{array}{l}\text { Retrospective } \\
\text { descriptive }\end{array}$ & $\begin{array}{l}\text { Emphysema } \\
\text { CT findings }\end{array}$ & 55 & $\begin{array}{c}\text { CT signs of emphysema, bullous lesions and cysts in } 42 \% \text { of } \\
\text { cases }\end{array}$ \\
\hline 1996 & $\begin{array}{l}\text { Guillemi } \\
\text { SA [22] }\end{array}$ & NR & $\begin{array}{l}\text { Prospective } \\
\text { descriptive }\end{array}$ & $\begin{array}{l}\text { Emphysema } \\
\text { CT findings }\end{array}$ & 32 & CT signs of emphysema in $31 \%$ of cases \\
\hline 1999 & $\begin{array}{l}\text { Diaz PT } \\
{[20]}\end{array}$ & NR & $\begin{array}{l}\text { Prospective } \\
\text { Case-control }\end{array}$ & Emphysema & $\begin{array}{c}96 \\
(30 \\
\text { controls })\end{array}$ & $\begin{array}{l}C T \text { signs of emphysema in } 50 \% \text { of cases in patients with } \\
\text { reduced } D_{L, ~ c o}\end{array}$ \\
\hline 2000 & $\begin{array}{l}\text { Diaz PT } \\
\text { [23] }\end{array}$ & $\begin{array}{l}1994- \\
1997\end{array}$ & $\begin{array}{l}\text { Prospective } \\
\text { Case-control }\end{array}$ & Emphysema & $\begin{array}{c}114 \\
(44 \\
\text { controls })\end{array}$ & $\begin{array}{l}\text { Increased incidence of emphysema in the HIV-infected } \\
\text { population (15\% versus } 2 \% \text { in controls }(p=0.025))\end{array}$ \\
\hline 1993 & $\begin{array}{l}\text { Nieman } \\
\text { RB [25] }\end{array}$ & $\begin{array}{l}1986- \\
1991\end{array}$ & $\begin{array}{c}\text { Cohort } \\
\text { descriptive }\end{array}$ & $\mathrm{T}_{\mathrm{L}, \mathrm{CO}}$ & 84 (AIDS) & $\begin{array}{c}\text { Decline in } T_{L,} \text { co significantly associated with more rapid } \\
\text { progression to AIDS }\end{array}$ \\
\hline 1993 & $\begin{array}{l}\text { Mitchell } \\
\text { DM [27] }\end{array}$ & NR & $\begin{array}{c}\text { Cohort } \\
\text { descriptive }\end{array}$ & $\mathrm{D}_{\mathrm{L}, \mathrm{CO}}$ & 474 & 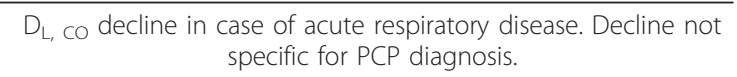 \\
\hline 1995 & $\begin{array}{l}\text { Rosen MJ } \\
\text { [29] }\end{array}$ & $\begin{array}{c}1988- \\
1994\end{array}$ & $\begin{array}{l}\text { Prospective } \\
\text { Case-control }\end{array}$ & $D_{L, C O}$ & $\begin{array}{c}1127 \\
(167 \\
\text { controls) }\end{array}$ & $\begin{array}{c}\text { CD4 }<200 / \mathrm{mm} 3 \text {, ethnic origin, smoking, IV drug use associated } \\
\text { with } \mathrm{D}_{\mathrm{L}, \text { co decline }}\end{array}$ \\
\hline
\end{tabular}


trend towards lower cumulative smoking $(12.2 \pm 0.9$ vs $17.2 \pm 3.2$ pack-years, $\mathrm{p}=0.13$ ) [13]. $\mathrm{D}_{\mathrm{L}}$, CO was lower in these patients, and a trend towards lower FEV1 was reported $(91.8 \pm 0.7 \%$ vs $94.9 \pm 1.8 \%, \mathrm{p}=0.12)$. Among HIV-infected subjects, respiratory symptoms were more frequent in smokers, IV drug users, patients with a history of asthma. In a population of AIDS patients undergoing routine pulmonary function tests (PFT), the estimated prevalence of reduced forced expiratory flow rates was 33\% [14].

Airways involvement has also been suggested in a CTscan study of 59 subjects, which found evidence of expiratory air trapping in 30/48 HIV-infected patients versus 3/11 HIV-seronegative subjects [15]. Air trapping was associated with lower FEV1 and $\mathrm{D}_{\mathrm{L}}$, CO. Subjects with air trapping tended to have lower $\mathrm{CD} 4$ counts, but the difference was far from significant $(p=0.40)$. Both acute and chronic respiratory tract infections play a noteworthy role in bronchial obstruction [16]. Pulmonary infections (Pneumocystis carinii pneumonia, bacterial pneumonia) are associated with durable changes in respiratory function in HIV-infected patients. The Pulmonary Complications of HIV Infection Study Group performed PFT every 3 to 12 months in 1149 HIVinfected patients between 1988 and 1994 [17]. In this cohort, 141 patients having had Pneumocystis carinii pneumonia (PCP) or bacterial pneumonia were followedup, and a permanent decrease in $\mathrm{FEV}_{1}, \mathrm{FVC}$ and $\mathrm{FEV}_{1} /$ FVC ratio was observed, lasting several months after resolution of the acute episode. In contrast, the decline in respiratory function following pulmonary tuberculosis was not accelerated by HIV co-infection [18].

HIV infection appears to be associated with parenchymal involvement, and especially emphysema. In 1992, Diaz et al. [19] reported the cases of four HIV-infected patients (including 3 smokers) with no history of pulmonary infection, who presented with dyspnea and were diagnosed with "emphysema-like syndrome". Pulmonary function tests showed air trapping, hyperinflation and reduction in $\mathrm{CO}$ diffusing capacity despite minimal airflow obstruction. Computed tomographic scans were performed in three of these patients and revealed bullous changes, pointing to a possible link between HIV infection and emphysematous pulmonary tissue destruction [19]. The same authors, in a population with no history of pulmonary infection but with diminished diffusing capacity of the lung for carbon monoxide $\left(D_{L}\right.$, co) (< $72 \%$ predicted), found CT evidence of emphysema in $50 \%$ of cases [20]. In another study of 55 patients with AIDS, radiological evidence of emphysema, bullous lesions or cysts was found in $42 \%$ of cases and was associated with a history of pulmonary infection in $70 \%$ of cases [21]. During routine CT studies prior to initiation of primary PCP prophylaxis, signs of emphysema were found in $31 \%$ of cases [22]. A study published in 2000 compared lung function in 114 HIVinfected patients (enrolled between 1994 and 1997) and 44 uninfected controls matched for age, sex and smoking status [23]. The authors confirmed the higher incidence of emphysema associated with HIV infection ( $15 \%$ versus $2 \%, \mathrm{p}=0.025$ ). The difference seemed to be even more marked among smokers. However, it should be noted that fewer than $10 \%$ of these patients, studied between 1994 and 1997, were receiving HAART.

Several studies have shown abnormal CO diffusion in HIV-infected patients, but the exact origin of this abnormality has not been determined. Diaz et al.[20] found that diffusion impairment in HIV-infected patients was associated with loss of capillary blood volume $(\mathrm{Vc})$ and not with an alteration of the membrane component $(\mathrm{Dm})$. This suggests that the decline in $\mathrm{T}_{\mathrm{L}}$, CO is not related to infiltration of the alveolar space or interstitium but rather to vascular abnormalities or emphysema. Reduced carbon monoxide transfer factor $\left(\mathrm{T}_{\mathrm{L}}, \mathrm{CO}\right)$ values were observed outside the context of respiratory tract disease [24,25], and also during the acute phase of PCP $[16,26-28]$. The reduction in $\mathrm{D}_{\mathrm{L}}$, CO appears to be significantly more marked in patients with CD4 cell counts below $200 / \mathrm{mm} 3$ [29] and to correlate with more rapid progression to AIDS [25]. It may be linked to pulmonary inflammation related to immunodeficiency. In some patients, the reduction in $\mathrm{D}_{\mathrm{L}}$, CO can also be related to undiagnosed HIV-related pulmonary hypertension [30].

Before the widespread use of HAART, several observations showed connections between COPD and HIV. Particular, emphysematous and bullous diseases have been described in young patients. Respiratory tract infections (opportunistic or not) were very common during this period and may had played a major role in the pathogenesis of COPD. As morbidity and mortality were essentially due to AIDS at that time, the impact of obstructive lung disease was not well known.

\section{COPD-HIV interaction in the HAART era (Table 2)}

The impact of HAART on respiratory disorders can be envisaged from different angles. On the one hand, assuming that HIV has inherent pathogenicity for the respiratory tract, HAART could prevent COPD by inhibiting viral replication. It could also prevent COPD by reducing the frequency of opportunistic infections and their long-term consequences.

On the other hand, the increase in life expectancy among HIV-infected patients, who have a high prevalence of smoking, could lead to an increase in the incidence of COPD. Nevertheless, no increase in the prevalence of airway obstruction has been observed among HIV-infected patients in recent years. 
Table 2 Main published studies on COPD-HIV interaction in the HAART era

\begin{tabular}{|c|c|c|c|c|c|c|}
\hline $\begin{array}{l}\text { Year of } \\
\text { publication }\end{array}$ & $\begin{array}{c}\text { First } \\
\text { Author } \\
\text { reference }\end{array}$ & $\begin{array}{l}\text { Study } \\
\text { period }\end{array}$ & $\begin{array}{l}\text { Type of } \\
\text { study }\end{array}$ & Focus & $\begin{array}{l}\text { Number } \\
\text { of } \\
\text { patients }\end{array}$ & Main findings \\
\hline 2005 & $\begin{array}{c}\text { Crothers K } \\
\text { [32] }\end{array}$ & $\begin{array}{l}1999- \\
2000\end{array}$ & $\begin{array}{l}\text { Observational } \\
\text { study } \\
\text { prospective } \\
\text { cohort }\end{array}$ & $\begin{array}{l}\text { Respiratory } \\
\text { symptoms }\end{array}$ & 867 & $\begin{array}{c}\text { Smoking associated with increase in respiratory symptoms; } \\
\text { cough and dyspnea found in } 44 \% \text { of smokers and } 25 \% \text { of } \\
\text { non smokers }\end{array}$ \\
\hline 2006 & $\begin{array}{c}\text { Crothers K } \\
\text { [31] }\end{array}$ & $\begin{array}{l}2001- \\
2002\end{array}$ & $\begin{array}{l}\text { Observational } \\
\text { study } \\
\text { Prospective } \\
\text { Case-control } \\
\text { Cohort }\end{array}$ & $\begin{array}{l}\text { COPD } \\
\text { (self-assessment and } \\
\text { coding data) }\end{array}$ & $\begin{array}{c}1014 \\
(713 \\
\text { controls) }\end{array}$ & $\begin{array}{l}\text { Self-assessment: prevalence of COPD significantly higher in } \\
\text { HIV-infected patients ( } 15 \% \text { vs } 12 \%, p=0.04) ; H I V \text { infection = } \\
\text { independent risk factor for COPD }\end{array}$ \\
\hline 2009 & $\begin{array}{c}\text { George MP } \\
\text { [33] }\end{array}$ & $\begin{array}{l}2003- \\
2004\end{array}$ & $\begin{array}{l}\text { Observational } \\
\text { study } \\
\text { Prospective }\end{array}$ & $\begin{array}{l}\text { Respiratory } \\
\text { symptoms. } \\
\text { airway obstruction }\end{array}$ & 234 & $\begin{array}{c}\text { Prevalence of airway obstruction: 6.8\%. Age, pack-years, } \\
\text { history of bacterial pneumonia and HAART = independent } \\
\text { risk factors for airway obstruction }\end{array}$ \\
\hline 2009 & $\begin{array}{c}\text { Morris A } \\
{[43]}\end{array}$ & NR & $\begin{array}{l}\text { Observational } \\
\text { study } \\
\text { Prospective }\end{array}$ & $\begin{array}{l}\text { Pneumocystis } \\
\text { colonization and } \\
\text { airway obstruction }\end{array}$ & 42 & $\begin{array}{c}\text { Colonization by Pneumocystis jirovecii ( } 26 \% \text { of cases) } \\
\text { associated with increase in airway obstruction and sputum } \\
\text { metalloprotease (MMP 12) levels }\end{array}$ \\
\hline 2010 & $\begin{array}{l}\text { Drummond } \\
\text { MB [36] }\end{array}$ & 1988-? & $\begin{array}{c}\text { Observational } \\
\text { study } \\
\text { Prospective } \\
\text { Cohort } \\
\text { Case-control }\end{array}$ & $\begin{array}{l}\text { Respiratory } \\
\text { symptoms. } \\
\text { Airway } \\
\text { obstruction }\end{array}$ & $\begin{array}{c}288 \\
(686 \\
\text { controls })\end{array}$ & $\begin{array}{l}\text { Prevalence of airway obstruction: } 15.5 \% \text {. No influence of HIV } \\
\text { status }\end{array}$ \\
\hline 2010 & Cui Q [35] & NR & $\begin{array}{l}\text { Observational } \\
\text { study } \\
\text { Prospective }\end{array}$ & $\begin{array}{c}\text { Respiratory } \\
\text { symptoms. } \\
\text { Airway obstruction }\end{array}$ & 119 & $\begin{array}{c}\text { No acceleration of } \mathrm{FEV}_{1} \text { decline relative to published data for } \\
\text { general population }\end{array}$ \\
\hline 2010 & $\begin{array}{l}\text { Gingo RM } \\
{[34]}\end{array}$ & $\begin{array}{l}2007- \\
2009\end{array}$ & $\begin{array}{l}\text { Cross- } \\
\text { sectional } \\
\text { analysis }\end{array}$ & Airway obstruction & 167 & $\begin{array}{l}64 \% \text { of patients had impaired diffusion. } \\
21 \% \text { of patients had irreversible airway obstruction. } \\
\text { Irreversible airway obstruction was independently associated } \\
\text { with HAART, pack-years smoked and intravenous drug use. }\end{array}$ \\
\hline 2011 & $\begin{array}{c}\text { Crothers K } \\
\text { [37] }\end{array}$ & $\begin{array}{l}1999- \\
2007\end{array}$ & $\begin{array}{c}\text { Observational } \\
\text { study } \\
\text { prospective } \\
\text { Cohort } \\
\text { Case-control }\end{array}$ & Coding data & $\begin{array}{c}3707 \\
(9980 \\
\text { controls) }\end{array}$ & $\begin{array}{l}\text { HIV-infected patients more likely to have diagnoses of COPD } \\
\text { (20.3 per } 1000 \text { person-years versus } 17.5 \text { per } 1000 \text { person-years } \\
\qquad-p<0.001) .\end{array}$ \\
\hline
\end{tabular}

In 2006, a prospective observational study comparing 1014. HIV-infected patients with 713 uninfected controls enrolled between 2001 and 2002 was published [31]. The prevalence of COPD was determined from coding data (International Classification of Diseases, ninth revision (ICD-9)) and also from a self-assessment in response to the question: "Has a doctor ever told you that you had a chronic lung disease (emphysema, asthma, chronic bronchitis, or chronic obstructive lung disease)?" In univariate analysis, based on the coding data, the prevalence of COPD was identical in the two populations; in contrast, the self-assessment suggested that the prevalence of COPD could be higher in the HIV-infected patients ( $15 \%$ vs $12 \%, \mathrm{p}=0.04)$. Indeed, multivariate analysis identified HIV infection as an independent risk factor for COPD (Figure 1) [31]. The lack of spirometric measurements and the failure to take into account environmental and occupational exposures are the main limitations of this study. Another study of a cohort of 867 HIV-infected patients showed that smoking was associated with an increase in respiratory symptoms; cough and dyspnea were found in $44 \%$ of smokers and $25 \%$ of non-smokers control [32].

A more recent prospective observational study examined the prevalence and risk factors of respiratory symptoms and airway obstruction in a population of 234 HIV-infected patients. The median CD4 count was 371 cells $/ \mathrm{mm}^{3}$ (interquartile range 3 - 1368). A majority of patients were on HAART (83\%). The duration of disease was 8 years among HAART users and 10 years among patients not using HAART. The prevalence of airway obstruction was $6.8 \%$ [33]. One year later, in a cross-sectional study, $167 \mathrm{HIV}$-infected patients had PFT [34]. The median CD4 count was 479 cells $/ \mathrm{mm}^{3}$ (interquartile range 22 - 1390). A majority of patients were on HAART (80.7\%). The median disease duration was 13 years (range 0.1-27). Irreversible airway obstruction was found in $21 \%$ of this population. Age, cumulative smoking history, a history of bacterial pneumonia, intravenous drug use and HAART were independent risk factors for bronchial obstruction (Figure 2) [33,34]. In contrast, a cross-sectional study establishing a link 


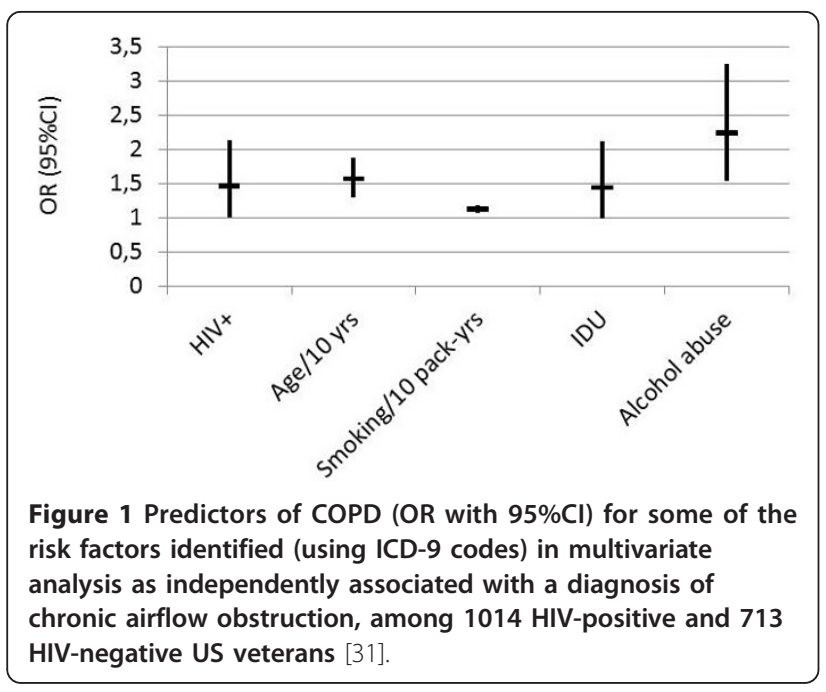

between cumulative smoking and $\mathrm{FEV}_{1}$ in 120 HIVinfected patients $(-2.1 \%$ of FEV1 per 10 pack-years) found a similar loss of $\mathrm{FEV}_{1}$ in HIV-infected smokers by comparison with published data for smokers in the general population [35]. However, this was a cross-sectional study, excluding a formal assessment of rates of FEV1 decline. In a cohort of IV drug users, the prevalence of airway obstruction was $15.5 \%$ overall and did not differ according to HIV status [36]. In this study, $54.6 \%$ of patients reported HAART use (median CD4 count 322 cells $/ \mathrm{mm}^{3}$ (interquartile range 177 - 503)) and the others had a median CD4 count of 321 cells $/ \mathrm{mm}^{3}$ (interquartile range 178 - 497). HIV status was not

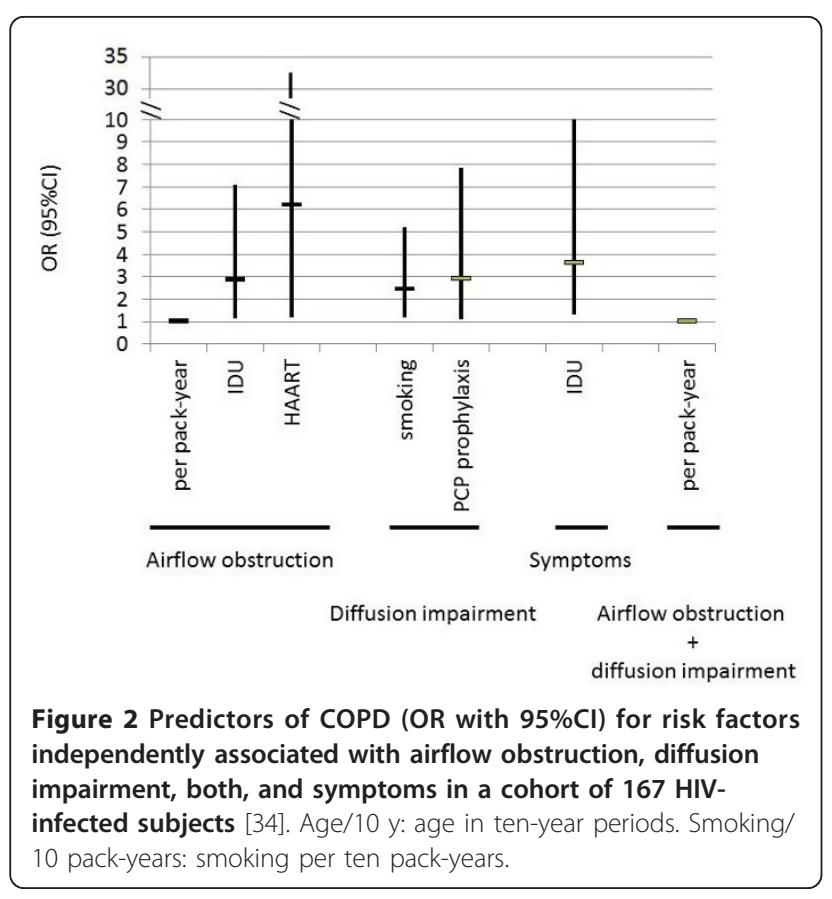

associated with chronic cough and sputum production either, but HIV-positive individuals reported moderateto-severe dyspnea (MRC dyspnea grade $\geq 2$ ) more frequently (OR 1.50, 95\%CI: 1.08-2.09). $\mathrm{D}_{\mathrm{L}}$, CO and CTscan were not available in this study, preventing from assessing the role of emphysema. Conversely, hemoglobin levels were slightly but significantly lower in HIV+ subjects, which could contribute to explain the higher frequency of dyspnea.

More recently, Crothers et al. assessed pulmonary diseases in a large cohort of $3707 \mathrm{HIV}$-infected patients (65\% on HAART; median CD4 count 264 cells $/ \mathrm{mm}^{3}$ (interquartile range 108 - 151)) [37]. This cohort was demographically matched to 9980 HIV-uninfected patients. Pulmonary conditions were diagnosed based on ICD-9 codes (International Classification of Diseases, ninth revision). HIV infection was independently associated with a significantly higher risk of COPD (20.3 per 1000 person-years versus 17.5 per 1000 person-years; $p$ $<0.001)$. Among HIV-infected subjects, the incidence of COPD was lower in patients on HAART ( $65 \%$ of the population studied) and in patients with baseline HIV RNA levels below 400 copies/ml [37].

\section{Factors underlying COPD-HIV interaction (Figure 3)}

Several factors are involved in the COPD-HIV interaction. Some are directly linked to HIV infection, others relate to its complications (colonization by Pneumocystis jirovecii, Pneumocystis jirovecii pneumonia, bacterial pneumonia, etc.) and its treatment. Other risk factors such as smoking and IV drug use are also more frequent in the HIV-infected population.

A possible role of HIV itself in the onset of COPD is supported by data on the pathophysiology of COPD. HIV infection causes intense pulmonary infiltration by

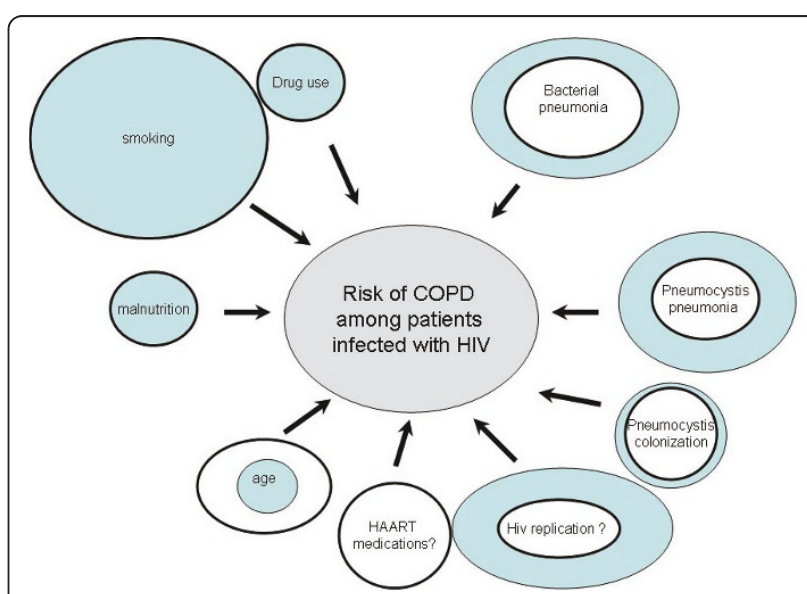

Figure 3 Factors underlying COPD-HIV interaction and their evolutions between pre-HAART era (blue circles) and HAART era (white circles). 
$\mathrm{CD}^{+}$lymphocytes, which are known to be involved in the development of COPD [3]. In addition, gammainterferon production is increased in the lungs of HIVinfected patients at different stages of the disease, including the asymptomatic phase [3]. However, the exact role of pulmonary effects of HIV infection in the pathogenesis of COPD remains to be determined. In addition, HIV transgene expression in rats and treatment of cell cultures with HIV-related proteins (gp120 and Tat) induce oxidative stress and reduce the expression of alveolar epithelial tight junctions, which may participate to explain lung function abnormalities in HIV-infected humans [38].

Recent data suggest that colonization by Pneumocystis jirovecii may also be involved in the development of COPD, by inducing an inflammatory reaction and stimulating the production of metalloproteases in the lung [39]. Pneumocystis jirovecii colonization correlates with the degree of bronchial obstruction, independently of smoking status, in HIV-seronegative COPD patients [39-41]. Pulmonary colonization by Pneumocystis jirovecii is frequent in HIV-infected patients, one study showing a prevalence of $46 \%$ in patients who died of causes other than PCP [42]. In a group of $42 \mathrm{HIV}$-infected patients with no signs of PCP, induced sputum analysis revealed Pneumocystis jirovecii colonization in 26\% of cases. Bronchial colonization by Pneumocystis jirovecii was associated with an increase in bronchial obstruction (reduction in $\mathrm{FEV}_{1}$ and the $\mathrm{FEV}_{1} / \mathrm{FVC}$ ratio) and an increase in sputum metalloprotease (MMP 12) levels [43]. In those studies, the CD4 cell count was not related to the risk of Pneumocystis colonization [42,43]. In a primate model of AIDS, $P$. jirovecii colonization was associated to COPD-like abnormalities, i.e. an accelerated decline in lung function and radiological and histological features of emphysema [44]. Th2 cytokines were increased in the BAL fluid of these animals, in which the proportion of airways associated with bronchus-associated lymphoid tissue was increased.

HIV-infected patients are at an increased risk of bacterial pneumonia. This risk increases markedly when the CD4+ cell count falls below $200 / \mathrm{mm} 3$, and in case of IV drug use [45]. A recent study confirmed that a history of bacterial pneumonia is an independent risk factor for airway obstruction in the HIV-infected population [33]. One mechanism underlying the deleterious effect of bacterial pneumonia on lung function decline among HIVinfected patients could be an HIV-induced increase in lung oxidative and nitrosative response to endotoxins, as found in a transgenic mouse model [46].

There also seem to be links between HAART and airway obstruction [33,34,37]. The study by Crothers et al. [37] showed a protective effect of HAART on the development of COPD, but airflow obstruction was not specifically examined. Conversely, in two other studies, HAART use was independently associated with bronchial obstruction [33,34].

Several pathophysiological explanations have been forwarded. Direct effects of HAART on the lung could exist, similar to HAART-associated cardiovascular disease, metabolic syndrome and osteoporosis. The Immune Reconstitution Inflammatory Syndrome (IRIS), a well-documented side-effect of HAART, might also be involved in airway obstruction. The restoration of the immune system could also induce an inflammatory response to sub clinical infections, perpetuating lung damage. It has also been hypothesized that an autoimmune response could develop after initiating HAART $[33,47]$.

The prevalence of airway obstruction in IV drug users appears to be high (15.5\%) but does not seem to differ according to HIV status [36]. In a large population of IV drug users, a reduction in $\mathrm{D}_{\mathrm{L}}$, CO was found in $42 \%$ of cases. This anomaly was usually isolated and was attributed to vascular phenomena (foreign particle emboli) [48]. Sherman et al. reported the cases of 6 patients who used methylphenidate (Ritalin ${ }^{\circledR}$ ) and presented with airway obstruction and a reduction in their $\mathrm{D}_{\mathrm{L}, \mathrm{CO}}$ values [49].

The prevalence of smoking among HIV-infected patients ranges from $40 \%$ to $70 \%$, compared to about $25 \%$ in the general population in the United States [4,35,50-54]. In the pre-HAART period, the impact of smoking on mortality among HIV-infected patients was controversial, some studies showing no difference between smokers and non-smokers [55,56], while others [57] showed more rapid disease progression and a higher risk of death among smokers. Since the advent of HAART, smoking has been identified as a significant risk factor for mortality among HIV-infected patients $[32,54]$, although the precise causes remain to be identified. Cardiovascular disorders and cancer probably also contribute to this higher mortality. More prolonged survival likely allows tobacco smoke to exert its deleterious effects and gives time for the corresponding diseases to become symptomatic. Interestingly, cannabis and tobacco smoke appear to produce synergistic effects on lung function, although the impact of cannabis alone is controversial [58]. This may be of particular relevance since (i) substance abuse is higher among HIV-infected subjects than in the general population [59] and (ii) medical marijuana has been legalized in some countries or states [60].

\section{Conclusion}

The prevalence of COPD is higher in the HIV-infected population than in the general population. Before the HAART era, respiratory tract infections were a very 
important risk factor. The advent of HAART has led to changes in HIV-related pulmonary diseases and to longer survival. COPD is emerging as a new source of morbidity in HIV-infected patients, with a deleterious synergistic interaction between HIV, smoking and COPD. These interactions deserve a particular attention, and efforts must focus on smoking prevention, particularly in the HIV-infected population. In HIV-infected patients (smokers and non smokers), clinicians should be aware that chronic respiratory symptoms necessitate $\mathrm{PFT}$ and lung imaging.

\section{Abbreviations}

AIDS: acquired immune deficiency syndrome; COPD: chronic obstructive pulmonary disease; $C T$ : computed tomography; $\mathrm{D}_{\mathrm{L}, \mathrm{co}}$ : diffusing capacity of the lung for carbon monoxide; $\mathrm{FEV}_{1}$ : forced expiratory volume in one second; FVC: forced vital capacity; HAART: Highly active antiretroviral therapy; HIV: Human immunodeficiency virus; $K_{c o}$ : Transfer coefficient; PCP: Pneumocystis carinii pneumonia; PFT: Pulmonary function tests; $T_{L}$, co: carbon monoxide transfer factor

\section{Author details}

'Service de pneumologie, Centre Hospitalier Victor Dupouy, 69 rue du L.C. Prud'hon, 95100 Argenteuil, France. ${ }^{2}$ Service de pneumologie et réanimation, Hôtel Dieu, AP-HP, Université Paris Descartes, 1 Place du parvis de Notre Dame, 75004 Paris, France. ${ }^{3}$ Service de pneumologie, Hôpital Saint Antoine, AP-HP, Université Pierre et Marie Curie, 184 rue du Fbg St Antoine, 75012 Paris, France.

\section{Authors' contributions}

All authors contributed to the literature analysis, writing and final validation of the manuscript. All authors read and approved the final manuscript.

\section{Competing interests}

The authors declare that they have no competing interests.

Received: 30 March 2011 Accepted: 1 September 2011 Published: 1 September 2011

\section{References}

1. Bourdin A, Burgel PR, Chanez P, Garcia G, Perez T, Roche N: Recent advances in COPD: pathophysiology, respiratory physiology and clinical aspects, including comorbidities. Eur Respir Rev 2009, 18:198-212.

2. Eisner MD, Anthonisen N, Coultas D, Kuenzli N, Perez-Padilla R, Postma D, Romieu I, Silverman EK, Balmes JR: An official American Thoracic Society public policy statement: Novel risk factors and the global burden of chronic obstructive pulmonary disease. Am J Respir Crit Care Med 2010, 182:693-718.

3. Petrache I, Diab K, Knox KS, Twigg HL, Stephens RS, Flores S, Tuder RM: HIV associated pulmonary emphysema: a review of the literature and inquiry into its mechanism. Thorax 2008, 63:463-469.

4. Hull MW, Phillips P, Montaner JS: Changing global epidemiology of pulmonary manifestations of HIV/AIDS. Chest 2008, 134:1287-1298.

5. Crothers K: Chronic obstructive pulmonary disease in patients who have HIV infection. Clin Chest Med 2007, 28:575-587.

6. Palella FJ Jr, Delaney KM, Moorman AC, Loveless MO, Fuhrer J, Satten GA, Aschman DJ, Holmberg SD: Declining morbidity and mortality among patients with advanced human immunodeficiency virus infection. HIV Outpatient Study Investigators. N Engl J Med 1998, 338:853-860.

7. Braithwaite RS, Justice AC, Chang CC, Fusco JS, Raffanti SR, Wong JB, Roberts MS: Estimating the proportion of patients infected with HIV who will die of comorbid diseases. Am J Med 2005, 118:890-898.

8. Krentz HB, Kliewer G, Gill MJ: Changing mortality rates and causes of death for HIV-infected individuals living in Southern Alberta, Canada from 1984 to 2003. HIV Med 2005, 6:99-106.
9. Magalhaes MG, Greenberg B, Hansen H, Glick M: Comorbidities in older patients with HIV: a retrospective study. J Am Dent Assoc 2007, 138:1468-1475.

10. Poirier $C D$, Inhaber $N$, Lalonde $R G$, Ernst P: Prevalence of bronchial hyperresponsiveness among HIV-infected men. Am J Respir Crit Care Med 2001, 164:542-545

11. Wallace JM, Stone GS, Browdy BL, Tashkin DP, Hopewell PC, Glassroth J, Rosen MJ, Reichman LB, Kvale PA: Nonspecific airway hyperresponsiveness in HIV disease. Pulmonary Complications of HIV Infection Study Group. Chest 1997, 111:121-127.

12. Moscato G, Maserati R, Marraccini P, Caccamo F, Dellabianca A: Bronchial reactivity to methacholine in HIV-infected individuals without AIDS. Chest 1993, 103:796-799.

13. Diaz PT, Wewers MD, Pacht E, Drake J, Nagaraja HN, Clanton TL: Respiratory symptoms among HIV-seropositive individuals. Chest 2003, 123:1977-1982

14. O'Donnell CR, Bader MB, Zibrak JD, Jensen WA, Rose RM: Abnormal airway function in individuals with the acquired immunodeficiency syndrome. Chest 1988, 94:945-948

15. Gelman M, King MA, Neal DE, Pacht ER, Clanton TL, Diaz PT: Focal air trapping in patients with HIV infection: CT evaluation and correlation with pulmonary function test results. AJR Am J Roentgenol 1999, 172:1033-1038.

16. Shaw RJ, Roussak C, Forster SM, Harris JR, Pinching AJ, Mitchell DM: Lung function abnormalities in patients infected with the human immunodeficiency virus with and without overt pneumonitis. Thorax 1988, 43:436-440.

17. Morris AM, Huang L, Bacchetti P, Turner J, Hopewell PC, Wallace JM, Kvale PA, Rosen MJ, Glassroth J, Reichman LB, Stansell JD: Permanent declines in pulmonary function following pneumonia in human immunodeficiency virus-infected persons. The Pulmonary Complications of HIV Infection Study Group. Am J Respir Crit Care Med 2000, 162:612-616.

18. Hnizdo E, Singh T, Churchyard G: Chronic pulmonary function impairment caused by initial and recurrent pulmonary tuberculosis following treatment. Thorax 2000, 55:32-38.

19. Diaz PT, Clanton TL, Pacht ER: Emphysema-like pulmonary disease associated with human immunodeficiency virus infection. Ann Intern Med 1992, 116:124-128

20. Diaz PT, King MA, Pacht ER, Wewers MD, Gadek JE, Neal D, Nagaraja HN Drake J, Clanton TL: The pathophysiology of pulmonary diffusion impairment in human immunodeficiency virus infection. Am J Respir Crit Care Med 1999, 160:272-277.

21. Kuhlman JE, Knowles MC, Fishman EK, Siegelman SS: Premature bullous pulmonary damage in AIDS: CT diagnosis. Radiology 1989, 173:23-26.

22. Guillemi SA, Staples CA, Hogg JC, Le AN, Lawson LM, Schechter MT, Montaner JS: Unexpected lung lesions in high resolution computed tomography (HRTC) among patients with advanced HIV disease. Eur Respir J 1996, 9:33-36.

23. Diaz PT, King MA, Pacht ER, Wewers MD, Gadek JE, Nagaraja HN, Drake J, Clanton TL: Increased susceptibility to pulmonary emphysema among HIV-seropositive smokers. Ann Intern Med 2000, 132:369-372.

24. Backer V, Nybo Jensen B, Pedersen C, Hertz JB, Jensen TH: Time-related decrease in diffusion capacity in HIV-infected patients with impaired immune function. Scand J Infect Dis 1992, 24:29-34.

25. Nieman RB, Fleming J, Coker RJ, Harris JR, Mitchell DM: Reduced carbon monoxide transfer factor (TLCO) in human immunodeficiency virus type I (HIV-I) infection as a predictor for faster progression to AIDS. Thorax 1993, 48:481-485.

26. Mitchell DM, Fleming J, Pinching AJ, Harris JR, Moss FM, Veale D, Shaw RJ: Pulmonary function in human immunodeficiency virus infection. A prospective 18-month study of serial lung function in 474 patients. Am Rev Respir Dis 1992, 146:745-751.

27. Mitchell DM, Fleming J, Harris JR, Shaw RJ: Serial pulmonary function tests in the diagnosis of P. carinii pneumonia. Eur Respir J 1993, 6:823-827.

28. Camus F, de Picciotto C, Gerbe J, Matheron S, Perronne C, Bouvet E: Pulmonary function tests in HIV-infected patients. AIDS 1993, 7:1075-1079.

29. Rosen MJ, Lou Y, Kvale PA, Rao AV, Jordan MC, Miller A, Glassroth J, Reichman LB, Hopewell PC: Pulmonary function tests in HIV-infected patients without AIDS. Pulmonary Complications of HIV Infection Study Group. Am J Respir Crit Care Med 1995, 152:738-745. 
30. Talwar A, Sarkar P, Rosen MJ: Pulmonary arterial hypertension in human immunodeficiency virus infection. Postgrad Med 2009, 121:56-67.

31. Crothers K, Butt AA, Gibert CL, Rodriguez-Barradas MC, Crystal S, Justice AC: Increased COPD among HIV-positive compared to HIV-negative veterans. Chest 2006, 130:1326-1333.

32. Crothers K, Griffith TA, McGinnis KA, Rodriguez-Barradas MC, Leaf DA, Weissman S, Gibert CL, Butt AA, Justice AC: The impact of cigarette smoking on mortality, quality of life, and comorbid illness among HIVpositive veterans. J Gen Intern Med 2005, 20:1142-1145.

33. George MP, Kannass M, Huang L, Sciurba FC, Morris A: Respiratory symptoms and airway obstruction in HIV-infected subjects in the HAART era. PLoS One 2009, 4:e6328.

34. Gingo MR, George MP, Kessinger CJ, Lucht L, Rissler B, Weinman R, Slivka WA, McMahon DK, Wenzel SE, Sciurba FC, Morris A: Pulmonary function abnormalities in HIV-infected patients during the current antiretroviral therapy era. Am J Respir Crit Care Med 2010, 182:790-796.

35. Cui Q, Carruthers S, Mclvor A, Smaill F, Thabane L, Smieja M: Effect of smoking on lung function, respiratory symptoms and respiratory diseases amongst HIV-positive subjects: a cross-sectional study. AIDS Res Ther 2010, 7:6

36. Drummond MB, Kirk GD, Ricketts EP, McCormack MC, Hague JC, McDyer JF, Mehta SH, Engels EA, Wise RA, Merlo CA: Cross sectional analysis of respiratory symptoms in an injection drug user cohort: the impact of obstructive lung disease and HIV. BMC Pulm Med 2010, 10:27.

37. Crothers K, Huang L, Goulet JL, Goetz MB, Brown ST, RodriguezBarradas MC, Oursler KK, Rimland D, Gibert CL, Butt AA, Justice AC: HIV Infection and Risk for Incident Pulmonary Diseases in the Combination Antiretroviral Therapy Era. Am J Respir Crit Care Med 2011, 183:388-395.

38. Lassiter C, Fan X, Joshi PC, Jacob BA, Sutliff RL, Jones DP, Koval M, Guidot DM: HIV-1 transgene expression in rats causes oxidant stress and alveolar epithelial barrier dysfunction. AIDS Res Ther 2009, 6:1.

39. Morris A, Sciurba FC, Norris KA: Pneumocystis: a novel pathogen in chronic obstructive pulmonary disease? COPD 2008, 5:43-51

40. Morris A, Sciurba FC, Lebedeva IP, Githaiga A, Elliott WM, Hogg JC, Huang L, Norris KA: Association of chronic obstructive pulmonary disease severity and Pneumocystis colonization. Am J Respir Crit Care Med 2004, 170:408-413.

41. Morris A, Netravali M, Kling HM, Shipley T, Ross T, Sciurba FC, Norris KA: Relationship of pneumocystis antibody response to severity of chronic obstructive pulmonary disease. Clin Infect Dis 2008, 47:e64-68.

42. Morris A, Kingsley LA, Groner G, Lebedeva IP, Beard CB, Norris KA: Prevalence and clinical predictors of Pneumocystis colonization among HIV-infected men. AIDS 2004, 18:793-798.

43. Morris A, Alexander T, Radhi S, Lucht L, Sciurba FC, Kolls JK, Srivastava R, Steele C, Norris KA: Airway obstruction is increased in pneumocystiscolonized human immunodeficiency virus-infected outpatients. J Clin Microbiol 2009, 47:3773-3776.

44. Shipley TW, Kling HM, Morris A, Patil S, Kristoff J, Guyach SE, Murphy JE, Shao X, Sciurba FC, Rogers RM, Richards T, Thompson P, Montelaro RC, Coxson HO, Hogg JC, Norris KA: Persistent pneumocystis colonization leads to the development of chronic obstructive pulmonary disease in a nonhuman primate model of AIDS. J Infect Dis 2010, 202:302-312.

45. Hirschtick RE, Glassroth J, Jordan MC, Wilcosky TC, Wallace JM, Kvale PA, Markowitz N, Rosen MJ, Mangura BT, Hopewell PC: Bacterial pneumonia in persons infected with the human immunodeficiency virus. Pulmonary Complications of HIV Infection Study Group. N Engl J Med 1995, 333:845-851

46. Jacob BA, Porter KM, Elms SC, Cheng PY, Jones DP, Sutliff RL: HIV-1induced pulmonary oxidative and nitrosative stress: exacerbated response to endotoxin administration in HIV-1 transgenic mouse model. Am J Physiol Lung Cell Mol Physiol 2006, 291:L811-819.

47. Beck JM, Rosen MJ, Peavy HH: Pulmonary complications of HIV infection Report of the Fourth NHLBI Workshop. Am J Respir Crit Care Med 2001, 164:2120-2126

48. Overland ES, Nolan AJ, Hopewell PC: Alteration of pulmonary function in intravenous drug abusers. Prevalence, severity, and characterization of gas exchange abnormalities. Am J Med 1980, 68:231-237.

49. Sherman CB, Hudson LD, Pierson DJ: Severe precocious emphysema in intravenous methylphenidate (Ritalin) abusers. Chest 1987, 92:1085-1087.

50. Arday DR, Tomar SL, Nelson DE, Merritt RK, Schooley MW, Mowery P: State smoking prevalence estimates: a comparison of the Behavioral Risk
Factor Surveillance System and current population surveys. Am J Public Health 1997, 87:1665-1669.

51. Niaura R, Shadel WG, Morrow K, Tashima K, Flanigan T, Abrams DB: Human immunodeficiency virus infection, AIDS, and smoking cessation: the time is now. Clin Infect Dis 2000, 31:808-812.

52. Patel N, Talwar A, Reichert VC, Brady T, Jain M, Kaplan MH: Tobacco and HIV. Clin Occup Environ Med 2006, 5:193-207.

53. Crothers K, Goulet JL, Rodriguez-Barradas MC, Gibert CL, Butt AA, Braithwaite RS, Peck R, Justice AC: Decreased awareness of current smoking among health care providers of HIV-positive compared to HIVnegative veterans. J Gen Intern Med 2007, 22:749-754.

54. Crothers K, Goulet JL, Rodriguez-Barradas MC, Gibert CL, Oursler KA, Goetz MB, Crystal S, Leaf DA, Butt AA, Braithwaite RS, Peck R, Justice AC Impact of cigarette smoking on mortality in HIV-positive and HIVnegative veterans. AIDS Educ Prev 2009, 21(3 Suppl):40-53.

55. Burns DN, Hillman D, Neaton JD, Sherer R, Mitchell T, Capps L, Vallier WG, Thurnherr MD, Gordin FM: Cigarette smoking, bacterial pneumonia, and other clinical outcomes in HIV-1 infection. Terry Beirn Community Programs for Clinical Research on AIDS. J Acquir Immune Defic Syndr Hum Retrovirol 1996, 13:374-383.

56. Galai N, Park LP, Wesch J, Visscher B, Riddler S, Margolick JB: Effect of smoking on the clinical progression of HIV-1 infection. J Acquir Immune Defic Syndr Hum Retrovirol 1997, 14:451-458.

57. Page-Shafer K, Delorenze GN, Satariano WA, Winkelstein W Jr: Comorbidity and survival in HIV-infected men in the San Francisco Men's Health Survey. Ann Epidemiol 1996, 6:420-430.

58. Tan WC, Lo C, Jong A, Xing L, Fitzgerald MJ, Vollmer WM, Buist SA, Sin DD: Marijuana and chronic obstructive lung disease: a population-based study. CMAJ 2009, 180:814-820

59. Chander G, Himelhoch S, Moore RD: Substance abuse and psychiatric disorders in HIV-positive patients: epidemiology and impact on antiretroviral therapy. Drugs 2006, 66:769-789.

60. Cinti S: Medical marijuana in HIV-positive patients: what do we know? J Int Assoc Physicians AIDS Care (Chic) 2009, 8:342-346.

doi:10.1186/1465-9921-12-117

Cite this article as: Raynaud et al.: Interactions between HIV infection and chronic obstructive pulmonary disease: Clinical and epidemiological aspects. Respiratory Research 2011 12:117.

\section{Submit your next manuscript to BioMed Central and take full advantage of:}

- Convenient online submission

- Thorough peer review

- No space constraints or color figure charges

- Immediate publication on acceptance

- Inclusion in PubMed, CAS, Scopus and Google Scholar

- Research which is freely available for redistribution

Submit your manuscript at www.biomedcentral.com/submit
C Biomed Central 